\title{
PERAN BAITUL MAAL WAT TAMWIL (BMT) AMANAH UMMAH TERHADAP PENINGKATAN USAHA PEDAGANG KECIL DI PASAR KARAH SURABAYA ${ }^{1}$
}

\author{
Puspa Indraswari \\ Mahasisiswa Program Studi S1 ekonomi Islam-Fakultas Ekonomi da Bisnis-Universitas Airlangga \\ Email: puspa.indraswari-12@feb.unair.ac.id/ HP: 087856877403 \\ Qudsi Fauzi \\ Departeen Ekonomi Syariah-Fakultas Ekonomi dan Bisnis-Universitas Airlangga \\ Email: qudsifauzy1@gmail.com / HP: 08123248103
}

\begin{abstract}
This study aims to analyze the role of BMT "Amanah Ummah" in empower the small traders. The research methods used in this research was case study qualitative method, using data collection techniques performed with conductive interviews and direct observation with the object of research. The result of this study indicate that BMT has been instrumental in increasing the business of small traders in Karah market. The business improvement from the small traders can be seen from the business turnover, business asset, business income and the stability of their business. The member of BMT in Karah market, on average has increased their business seen from their business volume, increasing of daily inventory such as equipment used for trade and revenues of their business income.
\end{abstract}

\section{Keyword: Baitul Maal Wat Tamwil, Empowerment, Business Improvement, Market}

\section{I.PENDAHULUAN}

Sistem keuangan Indonesia mengalami krisis yang mengakibatkan kelumpuhan aktivitas di hampir seluruh sektor perekonomian. Permasalahan disitermediasi sektor keuangan sesungguhnya terkait dengan berbagai alasan teknis yang disebabkan oleh tingginya tingkat risiko dan kemungkinan kerugian dalam aktivitas penanaman modal sektor rill. Namun dalam perspektif yang berbeda dapat dilihat bahwa instabilitas di sektor keuangan sangat terkait dengan instrumen dan sistem yang dominan digunakan di dalamnya, dalam hal ini sistem bunga (riba) sebagai satusatunya instrumen yang dimaksud (Satria., dkk. 2004)

Lembaga kevangan mikro Islam diyakini lebih mempertahankan dan ${ }^{[1]}$ Jurnal ini merupakan bagian dari Skripsi yang ditulis oleh Puspa Indraswari NIM 041211433014 yang diuji pada tanggal 30 Januari 2017 memperhatikan azas kemaslahatan bagi orang banyak, sehingga pembiayaan yang ditopang oleh lembaga keuangan mikro Islam harus menghindari kemungkinan hal-hal yang merusak moral masyarakat dan lingkungan serta harus memenuhi kriteria halal menurut syariah Islam. Selain itu setiap transaksi yang dibiayai oleh lembaga keuangan mikro Islam harus berorientasi langsung terhadap sektor rill sehingga sangat jelas bahwa dlam sistem kevangan Islam terjadi sinkronisasi antara perkembangan lembaga keuangan dan prokdutifitas di sektor rill.

Baitul Maal Wat Tamwil (BMT) atau yang juga dikenal dengan istilah Balai Usaha Mandiri Terpadu merupakan salah satu lembaga pendanaan alternatif yang 
Indraswari, et al/Jurnal Ekonomi Syariah Teori dan Terapan Vol. 5 No. 2 Februari 2018: 93-108; PERAN BAITUL MAAL WAT TAMWIL (BMT) AMANAH UMMAH TERHADAP PENINGKATAN USAHA PEDAGANG KECIL DI PASAR KARAH SURABAYA

beroprasi di tengah masyarakat akar rumput/sektor rill (Situmorang, 2006). Baitul Maal diperlukan masyarakat dengan pertimbangan-pertimbangan: masih terdapat kurang lebih 44,6 juta pengusaha kecil di Indonesia dan belum ada lembaga perbankan yang mampu berhubungan langsung dengan dengan pengusaha mikro, kecil dan menengah (Muhammad, 2009:6)

Oleh karena itu kehadiran BMT ditengah-tengah masyarakat ekonomi lemah, pada dasarnya merupakan jawaban atas belum terjamahnya dan terjangakau nya lapisan ekonomi lemah oleh lembaga-lembaga keuangan perbankan umum. Pertanyaan itu didasarkan pada daerah operasi BMT yang memfokuskan target pasarnya pada bisnis skala kecil yang kurang terjangkau oleh perbankan pada umumnya (Zainul, 1999:133).

Dalam kondisi yang demikian inilah BMT sebagai lembaga keuangan mikro berbasis syari'ah muncul dan mencoba menawarkan solusi bagi masyarakat kelas bawah. BMT merupakan kependekan dari Baitul Maal wa tamwil, secara harfiah/lughowi Baitul Maal berarti rumah dana dan baitul tamwil berarti rumah usaha. Kedua pengertian tersebut memiliki makna yang berbeda dan dampak yang berbeda pula. Baitul Maal dengan segala konsekuesinya merupkan lembaga social yang berdampak pada tidak adanya profit atau keuntungan duniawi atau material di dalamnya, sedangkan baitul tamwil merupakan lembaga bisnsi yang karenanya harus dapat berjalan sesuai prinsip bisnis yakni efektif dan efesien (Ridwan, 2006:1). Dengan adanya permasalahan diatas maka munculah pertanyaan terkait Bagaimana Peran Baitul Maal Waat Tamwil Terhadap Pemberdayaan Usaha Pedagang Kecil di Pasar Karah Surabaya?. Alasan memilih BMT Amanah Ummah adalah karena BMT Amanah Ummah adalah salah satu BMT di Jawa Timur yang telah sukses mengembangkan usahanya dari modal awal sebesar Rp 2.850.000 pada tahun 1995, hingga 15 tahun berjalan jumlah aset BMT Amanah Ummah sekarang berkisar Rp 4,3 Milyar.

\section{LANDASAN TEORI}

Lembaga keuangan mikro Islam atau yang biasa dikenal dengan Lembaga keuangan mikro syariah, menurut Muhammad (2009:78) adalah lembaga kevangan yang bekerja (beroperasi) untuk menjembatani kebutuhan masyarakat akar rumput, menurut prinsip dan konsep syariah dengan profit loss sharing sebagai metode utama. Dalam struktur lembaga keuangan mikro syariah 
Indraswari, et al/Jurnal Ekonomi Syariah Teori dan Terapan Vol. 5 No. 2 Februari 2018: 93-108;

PERAN BAITUL MAAL WAT TAMWIL (BMT) AMANAH UMMAH TERHADAP PENINGKATAN USAHA PEDAGANG KECIL DI PASAR KARAH SURABAYA

saat ini baru terdapat Baitul Maal Wat

Secara umum ciri utama BMT

Tamwil saja, tetapi dalam beberapa waktu kedepan akan berdiri lembaga kauangan mikro syariah yang lain. Namun nantinya Lembaga Keuangan mikro Islam yang akan berdiri tidak akan berbeda dari segi prinsip dan insturemen yang digunakan namun hanya memiliki perbedaan yang mendasar hanya pada skrup wilayah operasionalnya saja.

Sudarsono (2003:96) berpendapat bahwa, Baitul Maal Wat Tamwil (BMT) terdiri dari dua istilah baitul maal dan baitul Tamwil dalam artian bahasa adalah rumah harta (sosial) dan niga. Dalam pengertian yang lebih luas adalah lembaga keuangan yang melakukan kegiatannya untuk tujuan sosial dan niaga dalam rangka mensejahterakan umat yang dilakukan baik dengan menghimpun dana dari umat/masyarakat dan melakukan penyaluran dana/harta kepada yang berhak (fungsi Baitul Maal). Dengan demikian BMT pada dasarnya merupakan gabungan antara Baitul Maal dan Baitul Tamwil yang masing-masing memiliki karakteristik yang berbeda.

Sedangkan secara umum, ciri-ciri Baitul Mal Wat Tamwil dapat dibedakan menjadi dua yakni ciri jutama dan ciri khusus. Ciri-ciri utama BMT dijelaskan Ridwan (2004:132) sebagai berikut:

1. BMT berorientasi bisnis.

2. BMT bukan lembaga sosial.

3. BMT ditumbuhkan berlandaskan peran serta masyarakat sekitarnya.

4. BMT adalah dimiliki bersama.

menjelaskan BMT muncul dari peran aktif masyarakat disekitarnya dan dimiliki secara bersama-sama untuk meningkatkan perekonomian dengan melakukan praktek bisnsis dan fungsi sosial yang bermanfaat untuk kepentingan bersama dengan tujuan mencapai kesejahteraan masyarakat dan anggota bukan kepentingan sekelompok anggota semata.

Baitul Maal Wat Tamwil sebagai salah satu Lembaga Kevangan Mikro Islami memiliki bebrapa tujuan. Tujuan Baitul Mal Wa Tamwil sebagai suatu sistem koperas syariah dijelaskan Buchori (2009:18) sebagai berikut:

1. Mensejahterahkan anggotanya sesuai norma dan moral Islam.

2. Menciptakan persaudaraan dan keadila sesama anggota.

3. Pendistribusian pendapatan dan kekayaan yyang merata sesama anggota berdasarkan kontribusinya.

Selain itu mngenai tujuan dibentuknya Baitul Mal Wa Tamwil (BMT) dijelaskan Andriani (2005:254-255) sebagai berikut:

a. Meningkatkan dan mengembangkan ekonomi umat, khususnya pengusaha kecil.

b. Meningkatkan produktivitas usaha dengan memberikan pembiayaan.

c. Membebaskan umat/pedagang/pengusaha kecil dari bunga dan rentenir.

d. Meningkatkan kualitas dan kuantitas kegiatan usaha. 
Indraswari, et al/Jurnal Ekonomi Syariah Teori dan Terapan Vol. 5 No. 2 Februari 2018: 93-108;

PERAN BAITUL MAAL WAT TAMWIL (BMT) AMANAH UMMAH TERHADAP PENINGKATAN USAHA

PEDAGANG KECIL DI PASAR KARAH SURABAYA

e. Menghimpun dana dari umat Islam

yang tidak mau menyimpan dananya di Bank.

Penghimpunan dana oleh BMT diperoleh melalui simpanan, yaitu dana yang dipercayakan oleh anggota kepada BMT untuk kemudian disalurkan ke sektor produktif dalam bentuk pembiayaan (Widodo,dkk. 1999;83). Simpanan tersebut antara lain : (1) simpanan pokok tersebut sama dan tidak boleh dibedakan antara anggota. Akad Syariah pokok tersebut masuk katagori akad Musyarakah

Konsep pendirian BMT juga menggunakan konsep Musyarakah yakni sebuah usaha yang didirikan secara bersama-sama dua orang atau lebih, masing-masing memberikan kontribusi dana dalam porsi yang sama dan berpartisipasi dalam kerja dengan bobot yang sama pula. Masing-masing partner saling menanggung satu sama lain dalam hak dan kewajiban. Dan diperkenankan salah seorang memasukan modal yang lebih besar dan memperoleh keuntuga yag lebih besar pula dibanding dengan partner lainnya. (2) Simpanan Wajib, Simpanan wajib masuk dalam kategori modal BMT sebagaimana simpanan pokok di mana besar kewajibannya diutuskan berdasarkan hasil musyawarh anggota serta penyetorannya dilakukan scara kontinyu setiap bulannya sampai seseorang dinyatakan keluar dari keanggota BMT. Simapanan Sukarela, Simpanan anggota merupakan bentuk investasi dari anggota yang memliki kelebihan dana kemudian

menyimpannya di BMT. Bentuk simpanan sukarela ini memiliki 2 jenis karakter. Karakter pertama bersifat dana titipan yang disebut (Wadi'ah) dan dapat diambil setiap saat. Titipan (Wadi'ah) terbagi atas 2 macam yaitu titipan (Wa'diah) Yad dhamanah. Titipan Wadi'ah Yad Amanah merupakan titipan yang tidak boleh dipergunakan baik untuk kepentingan BMT maupun utuk investasi usaha, melainkan pihak BMT harus menjaga titpan tersebut sampai diambil oleh pemiliknya. Semantara titipan (wadi'ah) yad dhamanah adalah dana titipan anggota kepada BMT yang di izinkan utuk dikelola dalam usaha riil sepanjang dana tersebut belum diambil oleh pemilikna. Mengingat dana tersebut dapat dikelola maka sepantasnya BMT membebrikan kelebihan berupa bonus kepada penitip, meski tidak ada laranganuntuk tidak memberikan bonusnya.

Karakter kedua bersifat investasi, yang memang ditujukan untuk kepentingan usaha dengan mekanisme bagi hasil (Mudharabah) baik Revenue sharing maupun profit and lossharing.Konsep Simpanan yang diberlakukan dapat berupa simpanan berjangka Mudharabah Mutlaqah maupun simpan berjangka Mudharabah Muqayadah. Mutlaqah maupun simpanan berjangka Mudharabah muqayadah. Mudharabah Mutlaqah adalah bentuk kerja sama antara pemilik dana dengan (Shahibul Maal) dengan BMT selaku pengusaha (muharib) yang 
Indraswari, et al/Jurnal Ekonomi Syariah Teori dan Terapan Vol. 5 No. 2 Februari 2018: 93-108; PERAN BAITUL MAAL WAT TAMWIL (BMT) AMANAH UMMAH TERHADAP PENINGKATAN USAHA PEDAGANG KECIL DI PASAR KARAH SURABAYA

cakupnya snagat luas dan tidak dibatasi

oleh spesifikasi jenis usaha, waktu dan daerah usaha. Sementara Mudhabarah muqayah adalah bentuk kerjasama antara pemilik dana dengan BMT selaku pengusaha (mudharib) di mana penggunaan dana dibatasi oleh ketentuan yang dipersyaratkan oleh pemilik dana, dan merupakan kebalikan dari Mudharabah Mutlaqah. (4) Investasi pihak lain, Dalam melakukan operasionalnya BMT biasanya sangat membutuhkan suntikan dana agar dapat mengembangkan usahanya secara maksimal, mengingat prospek pasar yang cukup besar sementara simpanan anggotanya masih sedikit dan terbatas. Oleh karenanya diperbolehkan untuk bekerja sama dengan pihak-pihak lain seperti Bank Syariah maupun programpemerintah Investasi pihak lain ini dapat dilakukan dengan menggunakan konsep mudhorobah maupun konsep Musyarakah (www.koperasisyariah.com).

Dalam upaya peningkatan taraf hidup masyarakat, pola pemberdayaan yang tepat sasaran sangat diperlukan, bentuk yang tepat adalah dengan memberikan kesempatan kepada kelompok miskin untuk merencanakan dan melaksanakan program pembangunan yang telah mereka tentukan. Disamping itu masyarakat juga diberikan kekuasaan untuk mengelola dananya sendiri, baik berasal dari pemerintah maupun pihak amil zakat, inilah yang membedakan antara partispasi masyarakat dengan pemberdayaan masyarakat (Hutomo, 2000:2).

Pemberdayaan ekonomi ialah: usaha memberi pengetahuan, keterampilan, serta menumbuhkan kepercayaan diri serta kemauan kuat dalam diri seseorang sehingga mampu membangun suatu kehidupan sosialekonomi yang lebih baik dengan kekuatan sendiri. Singkatnya, pemberdayaan sosial-ekonomi bermaksud menciptakan manusia swadaya ekonomi.

Pemberdayaan ini pada intinya dapat diupayakan melalui berbagai kegiatan antara lain pelatihan, pendapmpingan, penyuluhan, pendidikan dan keterlibatan berorganisasi demi menumbuhkan dan memperkuat motivasi hidup dan usaha, serta pengembangan pengetahuan dan keterampilan hidup dan kerja (SPES, 1992:245).

Terdapat 4 konsep pemberdayaan menurut Sumodiningrat (1999) seperti yang dikutip oleh Hutomo (2000:6), secara ringkas dapat dikemukakan sebagai berikut:

1. Perekonomian rakyat adalah perekonomian yang diselenggarakan oleh rakyat. Perekonomian yang diselenggarakan oleh rakyat adalah perekonomian nasional yang berakar pada potensi dan kekuatan masyarakat secara luas untuk menjalankan roda perekonomian mereka sendiri. 
Indraswari, et al/Jurnal Ekonomi Syariah Teori dan Terapan Vol. 5 No. 2 Februari 2018: 93-108;

PERAN BAITUL MAAL WAT TAMWIL (BMT) AMANAH UMMAH TERHADAP PENINGKATAN USAHA

PEDAGANG KECIL DI PASAR KARAH SURABAYA

2. Pemberdayaan ekonomi rakyat adalah usaha untuk menjadikan ekonomi yang kuat, besar, modern, dan berdaya saing tinggi dalam mekanisme pasar yang benar. Karena kendala pengembangan ekonomi rakyat adalah kendala struktural, maka pemberdayaan ekonomi rakyat harus dilakukan melalui perubahan struktural.

3. Perubahan struktural yang dimaksud adalah perubahan dari ekonomi tradisional ke ekonomi modern, dari ekonomi lemah ke ekonomi kuat, dari ekonomi subsisten ke ekonomi pasar, dari ketergantungan ke kemandirian. Langkah-langkah proses perubahan struktur, meliputi: a) pengalokasian sumber pemberdayaan sumber daya;

b) penguatan kelembagaan; c) penguasaan teknologi; dan d) pemberdayaan sumber daya manusia.

4. Pemberdayaan ekonomi rakyat, tidak cukup hanya dengan peningkatan produktivitas, memberikan kesempatan berusaha yang sama, dan hanya memberikan suntikan modal sebagai stumulan, tetapi harus dijamin adanya kerjasama dan kemitraan yang erat antara yang telah maju dengan yang masih lemah dan belum berkembang.

5. Kebijakannya dalam pemberdayaan ekonomi rakyat adalah: a) pemberian peluang atau akses yang lebih besar kepada aset produksi (khusunya modal); b) memperkuat posisi transaksi dan kemitraan usaha ekonomi rakyat, agar pelaku ekonomi rakyat bukan sekedar price taker; c) pelayanan pendidikan dan kesehatan; d) penguatan industri kecil; e) mendorong munculnya wirausaha baru; dan f) pemerataan spasial.

6. Kegiatan pemberdayaan masyarakat mencakup: a) peningkatan akses bantuan modal usaha; dan b) peningkatan akses pengembangan SDM; dan c) peningkatan akses ke sarana dan prasarana yang mendukung langsung sosial ekonomi masyarakat lokal.

Adapun beberapa indikator pemberdayaan dalam meningkatkan usaha pedagang kecil yakni suatu usaha yang telah mengalami peningkatan usaha dapat diartikan telah mencapai keberhasilan usaha, dimana usaha tersebut mencapai kondisi yang sebelumnya belum pernah tercapai. Menurut Suryana (2003:85) suatu usaha dikatakan berhasil apabila setelah jangka waktu tertentu usaha tersebut mengalami peningkatan baik dalam permodalan, pendapatan, volume penjualan, output produksi dan tenaga kerja. Maka, peningkatan usaha dapat disamakan dengan keberhasilan usaha. Keberhasilan usaha juga diidentikan dengan perkembangan perusahaan, yaitu proses peningkatan kuantitas dan dimensi perusahaan. Perkembangan perusahaan adalah pertambahan karyawan, 
Indraswari, et al/Jurnal Ekonomi Syariah Teori dan Terapan Vol. 5 No. 2 Februari 2018: 93-108;

PERAN BAITUL MAAL WAT TAMWIL (BMT) AMANAH UMMAH TERHADAP PENINGKATAN USAHA

PEDAGANG KECIL DI PASAR KARAH SURABAYA

peningkatan aset, omset penjualan, dan

lain-lain (Jarkasih, 2008)

Tujuan hidup dalam Ekonomi Islam adalah tercapainya falah bagi seluruh umat. Falah berasal dari bahas arab dari kata kerja alfaha-yuflihu yang berarti kesuksesan, kemuliaan atau kemenangan tidak hanya di dunia tetapi juga di akhirat (P3El. 2007:2). Dalam kepentingan dunia, falah dibagi atas tiga pengertian, yaitu kekutan dan kehormatan, kebebasan berkeinginan serta kelangsungan hidup. Untuk kepentingan akhirat falah dibagi atas, kesejahteraan abadi, kemuliaan abadi, kelangsungan hidup yang abadi dan pengetahuan abadi (terbebas dari kebodohan).

Menurut Al-Ghazali, kesejahteraan (maslhah) dari suatu masyarakat tergantung pada pencarian dan pemeliharaan lima tujuan dasar; (1) agama (al-dien), (2) hidup atau jiwa (nafs), (3) keluarga atau keturunan (nash), (4) harta atau kekayaan (maal), (5) intelek atau akal (aql). Selanjutnya Al-Ghzal juga mementingkan bahwa sesuai tuntunan wahyu "kebaikan dunia dan akhirat (maslahat al-din wa al-dunya) merupakan tujuan utama" (Karim, 2007:62).

Selain itu, Al-Ghazali mengartikan kesejahteraan dalam aspek ekonomi daam kerangka hakiki utilitas individu dan sosial yang meliputi: kebutuhan dasar (darury), kenyamanan atau kesenangan (hajjiyi), dan kemewahan (tashniy). Kunci pemeliharaan dari kelima tujuan dasar ini terletak pada penyediaan kebutuhan dasar pada tingkatan pertama, yaitu

kebutuhan seperti makanan, pakaian, dan perumahan. Namun, Al-Ghazali juga menyebutkan bahwa kebutuhan tersebut cenderung dapat berubah sesuai dengan waktu dan tempat suatu masyarakat atau kelompok.

Pembiayaan pada BMT Amanah Ummah yang diberikan kepada pedagang kecil yang mempunyai usaha secara otomatis akan meningkatkan permodalan usaha. Peningkatan usaha akan memicu peningkatan lainnya dalam usaha seperti peningkatan omzet penjualan, pendapatan serta stabilitas usaha. Peningkatan modal diharapkan dapat meningkatkan produksi dan penjualan produk. Penjualan atau omzet usaha yang meningkat secara otomatis akan berpengaruh kepada peningkatan pendapatan usaha tersebut. Apabila suatu usaha dapat mengalami peningkatan penjualan dan pendapatan, dapat disimpulkan bahwa usaha yng dijalankan tersebut telah berjalan stabil atau mungkin mengalami peningkatan. Ketika suatu usaha dapat bertahan dalam jangka waktu tertentu, aset meningkat, penjualan atau omzet meningkat,atau pendapatannya meningkat dapat diartikan bahwa usaha tersebut telah mengalami peningkatan usaha karena telah mampu mengelola dan memperkuat potensi yang dimilikinya, serta mampu bertahan dalam menghadapi persaingan usaha sehingga berada pada suatu kondisi yang lebih baik dari periode sebelumnya. 
Indraswari, et al/Jurnal Ekonomi Syariah Teori dan Terapan Vol. 5 No. 2 Februari 2018: 93-108;

PERAN BAITUL MAAL WAT TAMWIL (BMT) AMANAH UMMAH TERHADAP PENINGKATAN USAHA PEDAGANG KECIL DI PASAR KARAH SURABAYA III. METODE PENELITAN

Pendekatan penelitian yang digunakan dalam penelitian ini adalah pendekatan kualitatif. Penelitian kualitatif menurut Bogdan dan Taylor (Moleong, 2000:3) adalah prosedur penelitian yang menghasilkan data deskriptif berupa katakata tertulis atau lisan dari orang-orang dan perilaku yang dapat diamati. Penelitian ini menggunakan pendekatan kualitatif deskriptif dengan metode studi kasus (case study). Menurut Sugiyono (2009:14) metode penelitian kualitatif adalah metode penelitian yang berlandaskan pada filsafat postpositivisme, digunakan untuk meneliti pada kondisi obyek yang alamiah, (sebagai lawannya eksperimen) dimana peneliti adalah sebagai instrument kunci, pengambil sampel sumber data dilakukan secara purposive dan snowball, teknik pengumpulan dengan triangulasi (gabungan), analisis data bersifat induktif/kualitatif, dan hasil penelitian kualitatif lebih menekankan makna dari pada generalisasi.

Alasan penulis menggunakan pendekatan kualitiatif deskriptif dalam penelitian ini bertujuan untuk menjawab rumusan masalah, yaitu "Bagaimana Peran Baitul Maal Wat Tamwil Terhadap Pemberdayaan Usaha Pedagang Kecil?". Pertanyaan "bagaimana" lebih tepat menggunakan pendekatan kualitatif, karena dalam penelitian ini, peneliti tidak memiliki peluang untuk melakukan kontrol terhadap obyek penelitian. Strategi yang digunakan dalam penelitian ini adalah studi kasus. Strategi studi kasus yang memungkinkan hasil penelitian yang mendalam dan sulit dimanipulsi karena peneliti hanya memiliki sedikit peluang untuk mengontrol peristiwa-peristiwa yang akan terjadi. Oleh karena itu, untuk mendapatkan sebuah jawaban yang tepat, dalam penelitian ini menggunakan pendekatan pendekatan kualitatif dan strategi studi kasus. Rumusan masalah tersebut membutuhkan jawaban dengan kajian yang mendalam, khususnya berkaitan dengan kajian literatur serta mengutamakan sumber bukti yang akurat melalui wawancara dan observasi secara langsung.

Berdasarkan tujuan penelitian yang hendak dicapai maka pendekatan kualitatif deskriptif adalah yang sesuai untuk digunakan dalam penelitian ini. Tujuan dari penelitian deskriptif ini adalah untuk membuat deskripsi, gambaran secara sistematis, aktual, dan akurat mengenai fakta-fakta yang benar-benar terjadi sesuai apa yang diteliti sehingga nantinya peneliti diharapkan dapat memahami fenomena yang dijadikan permasalahan dalam penelitian tersebut dan dapat diteliti secara aktual dan akurat sesuai dengan fakta-fakta yang ada di lapangan.

Dalam penelitian ini akan menggunakan studi kasus dalam memahami masalah yang akan di teliti. Studi kasus adalah metode penelitian yang secara khusus menyelidiki fenomena yang terdapat dalam konteks kehidupan nyata, yang dilaksanakan ketika batasan- 
Indraswari, et al/Jurnal Ekonomi Syariah Teori dan Terapan Vol. 5 No. 2 Februari 2018: 93-108;

PERAN BAITUL MAAL WAT TAMWIL (BMT) AMANAH UMMAH TERHADAP PENINGKATAN USAHA

PEDAGANG KECIL DI PASAR KARAH SURABAYA

batasan antar fenomena dan konteksnya

belum jelas (Yin, 2000:18). Hasil penelitian

yang menggunakan metode studi kasus

dinilai akurat dan sulit untuk dimanipulasi,

karena tidak adanya peluang bagi

peneliti untuk mengontrol peristiwa-

peristiwa yang akan terjadi. Studi kasus

memungkinkan peneliti untuk

mempertahankan karakteristik holistik dan

bermakna dari peristiwa-peristiwa

kehidupan nyata, seperti dari proses-

proses organisasional dan manajerial,

hubungan-hubungan internasional dan

kematangan industri (Yin, 2012:4). Oleh

karena itu, jawaban dan hasil dari hasil

sebuah penelitian yang tepat dalam

penelitian ini dapat dicapai dengan

menggunakan pendekatan kualitatif

deskriptif dan strategi studi kasus.

\section{Jenis dan Sumber Data}

Data dalam penelitian kualitatif dibagi menjadi dua yaitu data utama dan penunjang atau tambahan. Data utama merupakan data primer yang berasal dari hasil wawancara dan observasi langsung dari lapangan maka datanya lebih banyak berwujud kata-kata dan tindakan dari obyek penelitian atau dalam hal ini adalah masyarakat miskin. Dan penunjang merupakan data sekunder yang diperoleh dari suatu obyek penelitian yang berupa arsip, laporanlaporan masa lalu dan dokumendokumen yang relevan serta kajian pustaka yang berkaitan dengan permasalahan yang terjadi.

Penelitian ini menghimpun jenis data primer dan data sekunder. Data

primer adalah data yang dikumpulkan dan diolah sendiri oleh peneliti sedangkan data sekunder merupakan data yang diterbitkan oleh organisasi yang bukan pengelolahnya (Dajan, 1991:19) Jenis data dalam penelitian ini adalah sebagai berikut:

a. Data Primer

Menurut Umar (2003:56), data primer merupakan data yang diperoleh langsung di lapangan oleh peneliti sebagai obyek penulisan. Data primer yang digunakan sebagai sumber data adalah Wawancara dan observasi langsung kepada Pedagang kecil tentang bagaimana BMT Amanah Ummah dalam memberdayakan usaha pedagang kecil tetersebut. Wawancara dengan pengurus BMT Amanah Ummah Surabaya berkaitan dengan cara dan strategi apa saja dalam usaha pedagang kecil yang ada di pasar karah Surabaya. Bagaimana prosedur pelayananya, tata cara dan persyaratan, keadaan dan data penerima yang telah merasakan dampak dari program yang dimiliki BMT Amanah Ummah dalam memberdayakan usaha pedagang kecil ini dari lembaga tersebut serta informasi apa saja yang dapat digunakan agar dapat menjawab pertanyaan mengenai "Bagaimana Peran Baitul Maal Wat Tamwil dalam memberdayakan usaha pedagang kecil?"

b. Data Sekunder 
Indraswari, et al/Jurnal Ekonomi Syariah Teori dan Terapan Vol. 5 No. 2 Februari 2018: 93-108;

PERAN BAITUL MAAL WAT TAMWIL (BMT) AMANAH UMMAH TERHADAP PENINGKATAN USAHA PEDAGANG KECIL DI PASAR KARAH SURABAYA

Menurut Sugiyono (2005:62), data sekunder adalah data yang diperoleh tidak langsung memberikan data kepada peneliti, misalnya penelitian harus melalui orang lain atau mencari melalui dokumen. Data sekunder dalam penelitian ini yang pertama adalah berupa dokumen-dokumen yang di dapatkan dari BMT Amanah Ummah Surabaya yaitu berupa dokumen administrasi yang berkaitan dengan penelitian. Kedua berupa rekaman arsip, yaitu berupa rekaman pribadi yang berbentuk data pedagang-pedagang kecil yang telah merasakan dampak dari program BMT amanah Ummah Surabaya dalam meberdayakan ekonomi masyarakat miskin tersebut. Ketiga adalah berupa studi dokumentas yang dikumpulkan melalui berbagai sumber tertulis, seperti literatur-literatur yang relavan dengan penelitian ini, seperti majalah, surat kabar dan artikel dari internet yang relavan atau berkaitan dengan permasalahan.

Sumber dan jenis data dalam penelitian ini diperoleh dengan cara sebagai berikut:

Peneliti memeperoleh informan dengan cara purposive sampling yakni teknik pengambilan sampel sumber data dengan pertimbangan tertentu. Pertimbangan tertentu ini misalnya orang tersebut yang dianggap paling mengetahui tentang apa yang diharapkan atau sampel disini sebagai pengusaha, sehingga akan memudahkan peneliti menjelajahi objek atau situasi yang diteliti. Dengan kata lain pengambilan sampel diambil berdasarkan kebutuhan penelitian (Sugiyono, 2008:393).

\section{HASIL DAN PEMBAHASAN}

Hasil dari semua analisis yang dilakukan peneliti dari wawancara dan observasi langsung adalah BMT Amanah Ummah dalam memberikan pembiayaan kepada pedagang kecil bisa dikatakan mampu memberdayakan atau meningkatkan usaha pedagang kecil secara optimal. Berdasarkan atas data dan informasi yang peneliti temukan dilapangan, adanya program pembiayaan ini dikhususkan kepada masyarakat kecil yang sudah memiliki usaha tapi masih membutuhkan bantuan modal dalam meningkatkan volume usahanya, tanpa adanya bunga dan jaminan serta persyaratan yang mudah. Selain memberikan pembiayaan dalam bentuk produktif adapula pembiayaan yang sifatnya konsumtif yakni untuk memenuhi kebutuhan primer kepada masyarakat kecil yang dirasa memerlukan untuk tambahan kebutuhan mendesaknya. Program pembiayaan yang ada di BMT Amanah Ummah Surabaya adalah program 
Indraswari, et al/Jurnal Ekonomi Syariah Teori dan Terapan Vol. 5 No. 2 Februari 2018: 93-108;

PERAN BAITUL MAAL WAT TAMWIL (BMT) AMANAH UMMAH TERHADAP PENINGKATAN USAHA

PEDAGANG KECIL DI PASAR KARAH SURABAYA

pemberdayaan usaha masyarakat kecil

atau pedagang kecil yang mana di

fokuskan kepada usaha mikro tidak

semata mencari keuntungan saja tetapi

juga bersifat sosial dan bisnis karena

memiliki tujuan untuk memberdayakan

usaha pedagang kecil yang mulanya

kekurangan modal dan ingin

mengembangkan volume usahanya

menuju yang lebih baik lagi. Di suatu sisi,

motivasi atau upaya mensejahterakan

anggota melalui produk - produk

kevangan yang ada adalah saling tolong

- menolong dalam memenuhi kebutuhan

serta bersama - sama menjalankan

aktivitas ekonomi yang sesuai dengan

syariat islam sehingga visi ibadah juga

akan terlaksana dengan baik. Adapun hal

tersebut sesuai dengan firman Allah pada

QS. Al-Maidah : 2 yaitu :

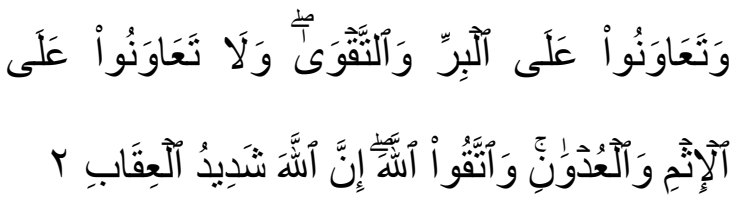

Artinya : "....Dan tolong-menolonglah kamu dalam (mengerjakan) kebajikan dan takwa, dan jangan tolong-menolong dalam berbuat dosa dan pelanggaran. dan bertakwalah kamu kepada Allah, Sesungguhnya Allah amat berat siksa-Nya.

sebagian besar informan mengalami peningkatan pada usahanya. Informan yang menerima pembiayaan menunjukan peningkatan usahanya yang terlihat dari peningkatan pada aset usahanya. Begitupula omzet penjualan usaha pada lima informan juga menunjukan adanya peningkatan. Sedangkan peningkatan usaha terjadi pada dua dari lima informan. Para anggota BMT Amanah Ummah yang menerima pembiayaan memang rata-rata adalah pedagang di pasar karah, mereka yang dijadikan informan dalam penelitian ini berjumlah lima orang dimana kelima informan ini menunjukan bahwa usaha yang dijalankan stabil setelah menerima pembiayaan dari BMT Amanah Ummah.

Dengan adanya pembiayaan yang ada di BMT Amanah Ummah Surabaya para penerima pembiayaan dilatih untuk bertanggung jawab terhadap dana yang diterimanya dan dapat dijadikan motivasi agar taraf hidupnya meningkat. Peminjam harus disadarkan tentang pentingnya penataan struktur keuangan, pinjaman kredit harus diartikan sebagai suntikan modal yang bersifat sementara karena pemberian pembiayaan harus mampu mendorong produksi yang akhirnya akan meningkatkan kapasitas usaha kecil yang berarti meningkatkan pendapatan dan meningkatkan kesejahteraan (Ridwan, 2004:28).

Pembiayaan yang ada di BMT Aamanah Ummah ini memang dimaksudkan untuk usaha mikro menengah yang lemah dalam mendapatkan modal usaha untuk 
Indraswari, et al/Jurnal Ekonomi Syariah Teori dan Terapan Vol. 5 No. 2 Februari 2018: 93-108; PERAN BAITUL MAAL WAT TAMWIL (BMT) AMANAH UMMAH TERHADAP PENINGKATAN USAHA PEDAGANG KECIL DI PASAR KARAH SURABAYA

mengembangkan usahanya sesuai dengan tujuan dari BMT Amanah Ummah. Masyarakat tidak hanya diberi modal begitu saja tetapi juga diberikan pelatihan atau edukasi bagaimana bersikap tanggung jawab dalam mengurus kevangannya sehingga mereka juga bisa mengendalikan cashflow nya. Selain itu juga dapat mempertanggung jawabkan kewajibannya dengan kerja keras dan usaha semaksimal mungkin. Selain itu pembiayaan ini diarahkan kepada penggunanya dalam kegiatan usaha yang produktif sehingga dapat berperan dalam mendorong peningkatan usaha yang lebih baik.

Pembiaayan murabahah produktif yang ditujukan kepada pedagang kecil yang membutuhkan modal ini juga tidak memberatkan penerimanya yaitu dengan tidak adanya bunga seperti lembaga keuangan yang lain karena lebih ke bagi hasil atau fee. Selain itu, tidak adanya jaminan dan persyaratan yang rumit sehingga memudahkan anggota dalam melakukan pembiayaan di BMT Amanah Ummah. Adapun infaq, shadaqah yang diberikan dari informan merupakan kerelaaan dari informan sendiri tanpa ada pemaksaan atau syarat sebelumnya yang mewajibkan berinfaq. Selain itu para anggota mengaku terbantu dalam meningkatkan usahanya dengan adanya pembiayaan di BMT Amanah Ummah ini, mereka dapat melakukan pembiayaan untuk menambah modal dagangnya selain itu angsuran yang dilakukan oleh informan dapat dilakukan harian, mingguan atau bulanan tergantung dengan akad pada awal. Selain menerima pembiayaan para anggota juga diwajibkan membuka tabungan di BMT jadi mereka bisa melakukan simpanan vang disana, rata-rata para informan yang menerima pembiayaan juga menyisihkan pendapatan mereka yang nantinya untuk ditabung atau melakukan angsuran. Setiap membayar angsuran, informan informan juga biasanya menyisipkan vang infaq seikhlasnya. Meskipun dari pihak BMT tidak melakukan pendampingan secara khusus tetapi hanya sekedar memantau saja, jika pelaku usaha mempunyai niat sungguh maka dapat berjalan deng baik sesuai harapan.

\section{Aset Usaha}

Peningkatan pada aset usaha merupakan salah satu bentuk perwujudan suatu usaha telah mengalami peningkatan. Menurut Tunngal (2002:1819), dalam suatu usaha, aset mempunyai fungsi penting untuk menunjang kegiatan produksi dimana merupakan sumber penghasilan yang dapat memberikan hasil pada masa sekarang dan pada masa yang akan datang. Aset usaha yang dimiliki oleh para pedagang di pasar karah yang menerima pembiayaan ratarata bertambah setelah menerima pembiayaan dari BMT Amanah Ummah. Aset tersebut berupa peralatan usaha seperti etalase, timbangan, blender, panci, pisau, meja, atau persedian bahan baku, pelengkapan usaha dan lain sebagainya yang diharapkan dapat 
Indraswari, et al/Jurnal Ekonomi Syariah Teori dan Terapan Vol. 5 No. 2 Februari 2018: 93-108; PERAN BAITUL MAAL WAT TAMWIL (BMT) AMANAH UMMAH TERHADAP PENINGKATAN USAHA PEDAGANG KECIL DI PASAR KARAH SURABAYA meningkatkan produksi maupun omzet penjualannya.

\section{Omzet Penjualan Usaha}

Omzet Penjualan yang terus mengalami peningkatan tertentu menunjukan bahwa terjadi peningkatan dalam usaha. Usaha yang tidak berkembang atau stagnan tidak akan mungkin mengalami peningkatan penjualan atau omzet. Menurut Chaniago (1995:14) omzet penjualan adalah keseluruhan jumlah pendapatan yang didapat dari hasil penjualan suatu barang atau jasa dalam kurun waktu tertentu.

\begin{tabular}{|c|c|c|}
\hline \multirow{2}{*}{ Informan } & \multicolumn{2}{|c|}{ Omzet Usaha } \\
\cline { 2 - 3 } & Sebelum & Sesudah \\
\hline $\mathbf{1}$ & $\operatorname{Rp~} 250.000$ & $\operatorname{Rp~} 300.000$ \\
\hline $\mathbf{2}$ & $\operatorname{Rp~} 125.000$ & $\operatorname{Rp~} 150.000$ \\
\hline $\mathbf{3}$ & $\operatorname{Rp~} 125.000$ & $\operatorname{Rp~} 200.000$ \\
\hline $\mathbf{4}$ & $\operatorname{Rp~} 200.000$ & $\operatorname{Rp~} 200.000$ \\
\hline $\mathbf{5}$ & $\operatorname{Rp~} 100.000$ & $\operatorname{Rp~} 150.000$ \\
\hline
\end{tabular}

observasi yang dilakukan peneliti di lapangan, semua informan mengalami peningkatan dalam omzet usahanya. Hasil penelitian menyatakan bahwa omzet para pedagang meningkat setelah menerima pembiayaan dari BMT Amanah Ummah. Di lihat dari peningkatan omset informan satu sampai lima yang sebelumnya omzet usahanya rendah setelah menerima pembiayaan dapat meningkat dari sebelumnya.

yang sebelumnya omzet usahanya rendah setelah menerima pembiayaan dapat meningkat dari sebelumnya. Omzet Usaha yang dimiliki oleh para pedagang di pasar karah yang menerima 
Indraswari, et al/Jurnal Ekonomi Syariah Teori dan Terapan Vol. 5 No. 2 Februari 2018: 93-108;

PERAN BAITUL MAAL WAT TAMWIL (BMT) AMANAH UMMAH TERHADAP PENINGKATAN USAHA

PEDAGANG KECIL DI PASAR KARAH SURABAYA

setelah menerima pembiayaan di

akibatkan karena volume usaha yang

bertambah sehingga mendorong

pendapatan yang meningkat pula tetapi

informan juga mengatakan bahwa yang mereka dapatkan kadang juga tidak menentu tergantung dari kondisi jualannya. Mereka tidak terlalu mementingkan besar pendapatan usahanya yang diterima setiap harinya, mereka lebih cenderung mementingkan pendapatan mereka yang di dapat dari hasil usahanya mampu mencukupi kebutuhan sehari-hari dan rumah tangganya.

Adanya pembiayaan ini diharapkan mampu membantu para pedagang kecil dalam meningkatkan usahanya terutama mereka yang butuh modal agar dapat mengembangkan volume usahanya, hal itu terbukti dengan adanya informan yang mengaku dapat memenuhi kebutuhan sehari-harinya karena pendapatan mereka yang meingkat.

\section{Stabilitas Usaha}

Stabilitas usaha yaitu kemampuan perusahaan untuk melakukan uahanya dengan stabil, yang diukur dengan mempertimbangkan kemampuan perusahaan untuk membayar kewajiban atas hutang-hutangnya termasuk tepat pada waktunya serta kemampuan menjalankan usahanya secara berkelanjutan tanpa mengalami hambatan atau krisis keuangan (Muwanir, 2000:31). Stabilitas usaha dapat diartikan sebagai kemampuan suatu usaha dalam

mempertahankan usahanya agar dapat tetap berjalan dengan baik berkelanjutan (continue) sehingga dapat mencapai peningkatan usahanya.

Dari hasil wawancara kelima informan yang telah diwawancarai mengaku bahwa usaha mereka dapat berjalan lancar setelah menerima pembiayaan dari BMT Amanah Ummah. Usaha yang mereka jalankan stabil dari waktu ke waktu. Kelancaran dan kestabilan usaha para pedagang kecil yang menerima pembiayaan di BMT Amanah Ummah menunjukan bahwa telah mampu meningkatkan stabilitas usaha para pedagang keci di pasar karah.

\section{KESIMPULAN}

Bentuk pemberdayaan yang diberikan kepada anggota BMT dengan tujuan memberdayakan usaha para angggota yang dilakukan oleh BMt Amanah Ummah dalam pemberian modal usaha kepada pedagang kecil ysng menjadi anggota BMT di pasar karah telah berhasil meningkatkan usahanya. Sebagai lembaga keuangan Islam yang merupakan salah satu solusi dan jawaban atas belum diperhatikan dan dijangkaunya usaha mikro kecil oleh lembaga keuangan perbankan. Berbagai upaya pun dilakukan oleh BMT dalam rangka mensejahterkan masyarakat kecil dengan membantu mereka memberikan pembiayaan untuk modal usaha atau menambah modal usahanya, dimana BMT mampu berperan aktif dalam 


\section{DAFTAR PUSTAKA}

Andriani. 2005. BAITUL MAAL WAT TAMWIL Konsep dan Mekanisme di Indonesia, (online), Volume

No.2,http://idb2.wikispaces.com/file/view/rd2 012.pdf, diakses 11 Oktober 2016.

Buchori, Alma. 2009. Manajemen Bisnis syariah. Bandung: Alfabeta

Chaniago, A. Arifinal, dkk. 1995. Ekonomi 2. Bandung: Angkasa.

Hutomo, Mardi Yatmo. 2000. Pemberdayaan Masyarakat dalam Bidang Ekonomi: Tinjauan Teoritik dan Implementasi. Jakarta: Bappenas

Jakarsih, Aan. 2008. Pengaruh Kemampuan Manejerial Pengusaha Terhadap Keberhasilan Usaha Pengusaha sepatu di Sentra Industri Kecil Persepatuan

Moleong, Lexy J. 2000. Metode Penelitian Kualitatif. Bandung: PT Remaja Rosdakarya

Muhammad. 2006. Bank Syariah Analisa Kekuatan, Kelemahan, Peluang dan Ancaman. Edisi Kedua. Yogyakarta: Ekonisia.

Munawir. 2000. Analisis laporan Keuangan. Yogyakarta: Liberty.

P3El. 2008. Ekonomi Islam. Rajawali Press: Jakarta.

Ridwan, Muhammad. 2004. Manajemen Baitul Maal Wat Tamwil (BMT). Yogyakarta: UII Press.

Satria, Dias dkk. 2004. Strategi Pengembangan Lembaga Kevangan Mikro Syariah (BMT - Baitul Maal Wat Tamwil) Dalam
Memberdayakan potensi Usaha Kecil. LKTM

Situmorang, Lusia dkk. 2006. Usaha Kecil Menengah dan Pembangunan. Jakarta: Ghalia Indonesia

Sudarsono, Heri, 2004. Bank Dan Lembaga Keuangan Syariah. Edisi Kedua. Yogyakarta: Ekonisia

Sugiyono.2009. Metode Penelitian Bisnis. Bandung: Alfabeta

Suryana. 2003. Kewirausahaan. Jakarta: Salemba Empat.

Tingkat Nasional Malang; Universitas Brawijaya.

Triyuwono, Iwan dan Mohammad As'udi. 2001. Akuntansi Syari'ah Memformulasikan Konsep Laba dalam Konteks Metfora Zakat. Jakarta: Salemba Empat

Tunggal, Amin Widjaja. 2002. Akuntasi Perusahaan Kecil \& Menengah. Jakarta: PT Rineka Cipta.

Umar, Husein. 2003. Metode Riset Komunikasi Organisasi. Jakarta: PT Gramedia Pustaka Utama

Widodo, Hertanto dkk. 1999. Panduan Praktis Operasional Baitul Maal Wat Tamwil. Bandung: Mizan

www.koperasisyariah.com (online) diakses pada tanggal 25 September 2016

Yin, Robert. 2012. Studi kasus Desain dan Metode Jakarta: PT Raja Grafindo Persada.

Zainul, Arifin.1999. Memahami Bank Syariah,Lingkup, Pelvang, Tantangan dan Prospek. Jakarta: Alvabet. 